\title{
Personalizam u Sjedinjenim Američkim Državama
} Bruno Matos*

\begin{abstract}
Sažetak
Problematika osobe, struktura njezinih društvenih, religijskih i epistemoloških komponenti prisutna je u sjevernoameričkoj filozofiji od ranih početaka, od puritanskog idealizma do bostonske i kalifornijske škole. Od sredine 18. stoljeća s problematikom osobe kao politički-društvenog subjekta bavili su se američki prosvjetitelji i transcendentalisti te su nastojali odgovoriti na pitanje kakav ravnopravan odnos treba uspostaviti izmedu legalno izabrane vlasti, ustanova i pojedinca. O osobi se raspravljalo unutar kritike individualizma, pri čemu je dotaknuta filozofsko-teološka rasprava o Božjoj osobnosti. Iako je u sjevernoameričkoj filozofiji idealizam postao dominantnim pravcem koji se razvija na sveučilištima, personalizam je s početka u odnosu na idealizam bio minoran, te je kasnije postao ravnopravnim sugovornikom u akademskom diskursu. Američki personalisti nisu nametali svoje spoznaje kao politički program ili svojevrsno religiozno učenje. Ipak u njima prepoznajemo zasebnu filozofsku refleksiju, koja poput personalizma u Europi pokušava odgovoriti na pitanje što je osoba s obzirom na teološke, prirodoznanstvene i sociološke postavke.
\end{abstract}

Ključne riječi: personalizam, integritet, impersonalizam, teizam, društvo

\section{Uvod}

Filozofi u Sjedinjenim Američkim Državama usvajali su problematična pitanja o ljudskoj osobi, svijesti i položaju u društvu u djelima Lockea, Humea, Hegela, Schopenhauera, Darwina i Spencera. Kako je filozofija tek kasnije, sredinom 19. stoljeća postala neovisnom akademskom disciplinom, koja se od tada predavala na zasebnim katedrama, osvrnut ćemo se na problematiku osobe u puritanskoj misli rane Amerike, koju obilježavaju polemike o politici, društvenom i crkvenom životu. Prekretnicu čini Bronson Alcott u teističkoj kritici transcendentalizma. Poslije ćemo izložiti personalističke ideje prisutne u američkom idealizmu, jer je on neposredno zaslužan za profilaciju personalizma na bostonskom i kalifornijskom sveučilištu. Iz kritičke analize idealizma proizlazi personalizam

* Dr. sc. Bruno Matos, Katolički bogoslovni fakultet Sveučilišta u Zagrebu. Adresa: Vlaška ul. 38, 10000, Zagreb, Hrvatska. E-adresa: bruno.vtz3@gmail.com 
Parkera Bownea. Treće razdoblje 20. stoljeća obilježavaju doprinosi Bowneovih učenika, kao i personalisti koji su se približili političko-društvenomu angažmanu borbe za prava Afroamerikanaca i američkih starosjedilaca.

\section{Personalističke ideje u ranoj sjevernoameričkoj filozofiji}

Govoreći o početcima personalističke misli u Sjevernoj Americi, moramo se prije svega osvrnuti na svjetonazor ranih Amerikanaca, koji su u 16. i 17. stoljeću naselili sjeveroistočne predjele, koji se danas nazivaju Novom Engleskom. To je područje zbog svojeg geostrateškog i ekonomskog položaja postalo važno u kasnijem naseljavanju, ali i industrijalizaciji Sjeverne Amerike. Puritanci su slijedili jedan oblik radikalnog kalvinizma, koji najbolje ilustrira filozofija Pierra Ramusa, čije su ideje puritanski teolozi prihvatili i širili. Pobornici radikalnog kalvinizma u Europi htjeli su srušiti njima omraženi monopol kralja i Crkve, ali su pri tome teško uspijevali. U Novoj Engleskoj te su ideje pale na plodno tlo jer su

putem društvenih ugovora ili pojedinačnih sporazuma organizirane male nezavisne zajednice, gradovi ili kongregacije, mala kraljevstva Kristova ili teokracije, u kojima su od naroda izabrane vlasti i svećenici zajednički bili odgovorni za prinuđeno poštivanje Božjeg zakona (Schneider, 1946, 6).

Za puritance je pitanje osobe bilo jednako relevantno koliko i ustrojstvo društvenog života.

U predodžbi idealne Božje i zemaljske vlasti prevladava koncept sveopće Božje djelatnosti u svijetu, pri čemu je pitanje slobodne volje i odluke nebitno: važno je poštivanje zemaljske vlasti kao poštivanje sklopljenog saveza, u čemu puritanski idealizam naglašava pasivnost osobnog prihvaćanja Božje volje. To jest,

fizički je svemir pod kontinuiranim nadzorom providnosti, stoga sve što se događa — kišno nevrijeme, epidemija ospica ili potresi — nije tek manifestacija prirodnog zakona, nego i božanskog suda. To su doslovno uzeti, božanski čini (Miller, 1953, 23).

Teološki koncept fizičkog svijeta u kojem je sve podloženo Božanskoj providnosti ne ostavlja prostora ljudskom su-djelovanju, što je osnovni element kršćanskog viđenja osobe jer osobnosti zapravo i nema ako nema slobodnog, potom i kreativnog su-dioništva u Božjem planu stvaranja. Takav stav mijenjao se s usvajanjem bajkonovske paradigme, koji je poslužio puritancima u suočavanju s novim političkim idejama američkih prosvjetitelja.

Charles Taylor nalazi određene poveznice u puritanskoj praksi kršćanstva između Bacona i Evanđelja: Puritanska praksa

dolazi iz religioznog pogleda koji nadahnjuje i samog Bacona. Okret od kontemplacije prema produktivnoj učinkovitosti koju jamči znanstveno istraživanje temelji se na biblijskom poimanju čovjeka kao instrumenta Božjeg stvaranja. Ljudi zapravo čine Božji posao u naporu oko usavršavanja i očuvanja stvorenih stvari, a povrh svega samih sebe(Taylor, 1989, 231). 
Ljudska osoba u puritanskom viđenju savršenog društva postaje Božjim sugraditeljem svijeta, što na neki način ublažava prijašnju interpretaciju djelovanja Božje providnosti.

Taj odnos koji definira osobu u smislu Božjeg oruđa približavaju dva termina: technologia, u kojoj ne promatram svijet kao danu harmoničnu cjelinu, i drugi, eupraxia, koji naglašava utjecaj pojedinca na svijet kojemu pomaže doći do harmoničnog poretka (Taylor, 1989, 233). Iako nam se čini da je filozofski problem položaja osobe u svijetu riješen u sprezi individue i kolektiva koje pomaže steći sklad pomoću znanosti, takvo viđenje osobe biva uskoro napušteno pod utjecajem američkog prosvjetiteljstva. Personalistička pitanja u ranoj američkoj filozofiji tako ostaju u domeni rasprava o odnosu individue i državne zajednice, kao i u kontekstu teologije, koja je počela problematizirati analogiju Božje i ljudske osobnosti. Razlog tomu leži u činjenici da se zanimanje za personalistička pitanja probudilo iz dva različita tabora: apologetsko-teističkoga i transcendentalističkoga.

\subsection{Pitanje osobe u transcendentalizmu}

Transcendentalizam se pojavljuje kao bunt protiv prosvjetiteljskog shvaćanja politike, društva i religije. Budući da je bejkonovski duh vladanja prirodom dominirao u poslijeratnom društvu koje je mijenjalo svoje naličje pod sve opsežnijom industrijalizacijom, kod transcendentalista nailazimo na drukčiji odnos. Kod transcendentalista

pobjeda čovjeka bila je više preko i nad prirodom nego kroz prirodu, a transcendentalisti su zauzeli jedan gospodareći stav upotrebljavajući prirodu za ono što je za njih moralno značila, ali pokazujući malo zanimanja za podrobnije spoznaje prirode ili za napredak eksperimentalne znanosti (Schneider, 280).

Drugim riječima, transcendentalisti nisu težili za ovladavanjem prirode putem znanosti, industrijskog iscrpljivanja njezinih resursa ili s ciljem pogodnijeg življenja cijele zajednice.

Štoviše, možemo pretpostaviti da su prezirali takav odnos smatrajući da pojedinac mora kroz prirodu i nadilazeći njezine zakonitosti dosegnuti jednu neopipljivu i apstraktnu razinu stvarnosti (Schneider, 280). Primjer takvog stava najbolje ilustrira idealizam Ralpha Walda Emersona. Ralph Waldo Emerson (1803.-1882.) bio je putujući propovjednik i predavač. U početku se u svojim radovima bavio $s$ teološkim pitanjima, a kasnije se u svojoj filozofiji posvetio pitanjima društva i politike. Ipak, njegova metoda filozofijskog mišljenja je više poetska nego diskurzivna, to jest »takav duh [Emersonov] bio je dvostruko subjektivan: on je bio više mašta nego znanje — poezija, a ne znanost; i kao svoj cilj imao je samospoznaju. Bila je to jedna sinteza introspekcije i refleksije koja je stvarala vrednovanje vlastite osobe, čas herojski, čas patetično« (Schneider, 284). Emersonov pristup osobnosti usvojili su njegovi učenici Walt Whitman i Henry Thoreau. 
Walt Whitman (1819.-1892.) u svojim je novinarskim, putopisnim i poetskim djelima na neizravan način doticao personalističku problematiku. Kritika američkog društva u kojem je naslijedio stil svojeg učitelja Emersona posebno se tiče odnosa individue i kolektiva. Naime, Whitman, kao gorljivi zagovornik Lincolnove politike nije bio protivnik demokratskog društva, nego temeljnih pretpostavki za njegovu održivost, koje se nisu mogle svoditi na puku građansku poslušnost pojedinaca. Iako se njegov individualizam opisuje kao "egotizam", Whitman time ne naglašava vrijednost pojedinca nad vrijednošću zajednice, nego ih stavlja u međusobnu povezanost: nacija će postojati sve dok su oni koji ju čine jake, zdrave i razvijene osobnosti (Symonds, 1893, 62). Njegov suvremenik Thoreau (1817.-1862.) također problematizira koncept osobnosti u formi poezije i proze u svojim djelima $A$ Week on the Concord and Merimaak Rivers i Walden - život u šumi.

Thoreau filozofira o pojedincu koji gradi svoj identitet u skladu s ciklusima i pojavama u prirodi: godišnjim dobima, kiši, zrenju plodova, smjenama dana i noći. Također, osoba koja kultivira sebe u prirodi nije neki apstraktan, generalni uzorak moralnog ponašanja, nego primjer filozofa. »Thoreau u Waldenu predstavlja prikaz Thoreaua u Waldenu. Stavlja pred nas egzemplarni individualni život u jednoj fazi razvoja. Predstavlja sljedećeg ja koji nije konačni ja « (Furtak, 2012, 28). U skoro poetskoj formi koja ga ne udaljuje od njegova učitelja Emersona, Thoreau opisuje život osobe, pojedinca u prirodnom okruženju u kojem je pozvan kultivirati svoje ja, kao da je riječ o nekom dobrovoljnom socijalnom pokusu.

\subsection{Personalizam Bronsona Alcotta}

Bronson Amos Alcott (1799.-1888.) u svojoj filozofiji razvija personalističke koncepte kako na početku pod utjecajem Emersona, tako kasnije, vraćajući se, osobito u poodmakloj dobi, kršćanskomu pravovjerju, pa čak i u teističkoj kritici Emersonova panteizma. Personalizam Bronsona Alcotta možemo nazvati teističkim u smislu njegova udaljavanja od transcendentalističkoga gledišta na narav Božje osobnosti. Iako su povjesničari američke filozofije istaknuli njegov prosvjetni angažman u Temple School i neuspjelom projektu Fruitlands, ${ }^{1}$ važno je istaknuti filozofsko-teološku problematiku koja je iznijela na vidjelo Alcottov personalizam. Naime, većina transcendentalista koji su se okupljali u Novoj Engleskoj bili su unitarijanci koji nisu samo odbacivali dogmu o Svetom Trojstvu, nego su bili otvoreni i drugim religijskim učenjima osim onih koje su poznavali kao kršćanske (Schepard, 1937, 249).

Takva vrsta slobodnog usvajanja drugih religijskih doktrina, vrsta eklektičkog pristupa religiji, dovela je Alcotta i transcendentaliste na drukčije kolosijeke. Transcendentalisti su držali do panteističkoga gledanja na stvarnost Boga i svije-

1 Alcott je zamislio Fruitlands kao idealnu zajednicu sastavljenu od pojedinaca i obitelji, koja bi imala značajke ranog engleskog i francuskog socijalizma. Njegov projekt nije zaživio, pod pretpostavkom nedostatka resursa, tehnologije i najvažnije, ljudi (Schepard, 1937, 360-361). 
ta: znanje koje Bog posjeduje jednako je znanju svake individualne duše (Schepard, 1937, 258). Alcott, koji je bio upoznat s temeljnim postavkama kršćanske teologije svakako se nije mogao pomiriti s takvim razvojem transcendentalističkoga creda. Emerson je sveo osobu Boga na neosobnu energiju, apstraktne koncepte pravednosti, zakona i sličnog, a Alcott je zamjerio toj religioznosti manjak interesa za glavno pitanje, na koje je kršćanska Objava davno odgovorila, a tiče se odnosa Boga i čovjeka (Schepard, 1937, 260).

U jednoj od svojih rasprava s Emersonom, Alcott transcendentalizam naziva "impersonalnim", 2 atribut koji su kasnije koristili američki personalisti u kritici idealizma, naturalizma i materijalizma. Kod Alcotta ne možemo izdvojiti neko djelo u kojem je sustavno izložio svoj personalizam, ipak, on je uvijek bio prisutan u njegovoj filozofiji. Naime, »Alcottovi su suvremenici vjerovali, krivo ili pravo, da je on bio prvi filozof koji je oblikovao personalističko gledište, i u tom slučaju njegov utjecaj nije tako neznatan, kako se mislilo« (Schepard, 1937, 499). Teističko-personalistička pitanja koje je Alcott otvorio u raspravi s Emersonom bila su i dalje otvorena u kasnijem razvoju personalizma na američkom tlu.

\section{Personalizam u razdoblju akademizma}

S razvojem urbanih sredina, u Sjevernoj Americi razvijaju se i visoka učilišta kao što su: Harvard, Yale, Stanford, Princeton, Kings College. Na njima se otvaraju filozofske škole različitih pravaca: idealizma, naturalizma, materijalizma i personalizma. Kako opisuje Schneider, filozofija do obnovljenog akademskog rada nije posjedovala neko izdvojeno mjesto među fakultetskim kolegijima, nego je bila integralni element u glavnim teološkim, političkim i ekonomskim sustavima misli, jer jednostavno nije bilo potrebe za filozofijom kao neovisnom disciplinom (Schneider, 442). U tom smislu sjevernoamerička je filozofija ušla u razdoblje akademizma, u kojem je inzistirala na sustavnom izlaganju filozofije kao znanstvene discipline. Budući da je filozofija postala zasebnim kolegijima na sveučilištima, praksa je zahtijevala predavače koji bi sustavno izlagali materiju koja je više nije ovisila o drugim disciplinama.

Zašto je obnavljanje filozofije kao zasebnog kolegija bitno za razvoj personalizma? Prije svega, teologija se na američkim sveučilištima morala suočiti s novim izazovima: Darwinom, materijalizmom i naturalizmom. Akademska filozofija još nije izišla iz obzorja idealizma, iako su upravo idealisti kao Hickok, Hocking i Calkins neposredno zaslužni za profilaciju personalizma jer su u svojim istraživanjima problematizirali ljudsku osobnost na koju su se kasnije referirali i persona-

2 U Alclottovu personalizmu Bog ima osobnost, zbog čega se odupire izjednačavanju indvidualizma i personalizma. Individualizam, koji je u određenoj mjeri bio prisutan u europskoj filozofiji, u američkoj misli poprima drukčije značenje i veže se uz kalvinističko značenje Istočnoga grijeha. Alcott je smatrao individualizam istočnim grijehom i prijetnjom demokraciji, što je pripisao transcendentalizmu (Schmidt, 1994). 
listi. Osim toga, morali su odgovoriti na izazovna pitanja u teorijama o osobnoj svijesti Roycea i Jamesa, koji su također bili sveučilišni predavači.

\subsection{Laurens Perseus Hickok}

Laurens Perseus Hickok (1798.-1888.) svoj je rad posvetio problematici ljudske spoznaje, o čemu govore i nazivi njegovih djela: Rational Psychology (New York, 1854.), Empirical Psychology (Chicago, 1873.), The Logic of Reason (New York, 1875.). U pristupu toj problematici, Hickok se oslanja na Hegela, njegovo poimanje Begriffe, koji smatra teško prevodivim na engleski jezik, te jednostavno definira kao »sebe-identitet u kojem se sjedinjuju subjektivna ili interna i objektivna ili izvanjska djelatnost mišljenja« (Hickok, 1875, 49). Hickok je tijekom svojeg filozofskog proučavanja bio zainteresiran za različite discipline: teologiju, etiku, antropologiju, epistemologiju, kozmologiju. Iako slijedi hegelijansku metodologiju, Hickok naglašava u Racionalnoj kozmologiji cilj filozofije kad je riječ o pitanju Božjeg postojanja, gdje podvlači jasne granice.

Ako je svemir apsorbiran u Božanskom, onda je to panteizam; ako se Božansko gubi u njemu onda je to pankozmizam. No, ne-filozofski panteizam lako postaje ateizmom, a ateističkim pankozmizmom lako je dovesti cjelokupno filozofijsko mišljenje do apsurda(Hickok, 1858, 21).

Hickok ulazi na personalističko područje nastojeći dokazati da je sama mogućnost čovjekova diskurzivnog ili logičkog mišljenja dostatni argument u pri$\log$ Božje osobnosti. Identitet Apsolutnoga ili Božanskoga propituje se i kod Mary Whiton Calkins, čiji apsolutni personalizam nastaje pod utjecajem Josiaha Roycea.

\subsection{Josiah Royce i Mary Whiton Calkins}

Josiah Royce (1855.-1919.), poput svojeg dugogodišnjeg prijatelja Williama Jamesa, bio je predavač filozofije na sveučilištima Berkeley i Harvard. Zastupao je apsolutni idealizam, ${ }^{3}$ čije osnove prenosi i na svoju učenicu Calkins, iako ga ona kasnije pomiruje s personalističkim gledištima. Filozofsko istraživanje kod Roycea započinje od problematike koja je ujedno spoznajna i socijalna. U analizi logičke zablude (eng. error) u svojoj Filozofiji religije, ${ }^{4}$ Royce daje zaključak da mi, usuglašujući različite stavove kao sugovornici ne možemo izbjeći zabludu, čak i ako tvrdimo da neka činjenica jest ili će biti vjerojatna. Ako kažemo da nešto može biti vjerojatno (i pritom možemo zapasti u zabludu ako opisana činjenica

3 U filozofskoj terminologiji na hrvatskom jeziku koristimo termin apsolutni idealizam, a apsolutizam se defnira kao oblik neograničene političke vlasti. U engleskom se jeziku absolutism definira i kao neograničena politička vlast i kao "metafizika o Apsolutnom" (Mautner, 1996, s. v. absolutism).

4 Na području angloameričke filozofije termini religious philosophy i philosophy of religion često se koriste kao istoznačnice. Ivan Devčić na primjeru Plotina govori o religioznoj filozofiji kao jedinstvenom modelu mudrosti u kojem se filozofsko mišljenje podređuje religiji, što se ne nazire u Royceovu idealizmu (Devčić, 2003, 149). 
ne odgovara stupnju vjerojatnosti suda), ništa zapravo ne tvrdimo, jer da bismo nešto smatrali vjerojatnim, polazimo od aktualnoga (Royce, 1952, 34). Kako bi sud nekog pojedinca bio valjan, on se ne može osloniti na mogućnosti vlastite spoznaje, nego na komplementaran karakter neke opće poznate i neupitne istine koja proizlazi iz Apsolutnog Sebstva (Absolute-Self).

Mary Whiton Calkins (1863.-1930.) također je obilježila razdoblje akademizma objavljujući priručnike iz filozofije. Iako je Calkins bitna za ranu povijest američke psihologije slično Hickoku, osim psihologije bavila se poviješću filozofije, osobito s Berkeleyem i Hobbesom. Iako usvaja postavke Royceova idealizma, ona se približava personalističkim pitanjima o spoznaji, svijesti i intuiciji. U njezinoj filozofiji stoga često nailazimo na pojam personalnog apsolutizma. Apsolutizam ima epistemičko i metafizičko naličje: kao epistemički konstrukt podrazumijeva postojanje jedne i stalne istine kao uvjet svake druge istine; kao metafizički konstrukt govori o Bitku kao nepromjenjivoj i sveobuhvatnoj stvarnosti, kao Apsolutnom (Calkins, 1925, 404). Kako bi pomirila koncept apsolutnog bitka i samospoznavajućeg subjekta, Calkins uvodi termin uključujuće sebstvo. Ja sam svjestan sebe, svojeg postojanja, ali sam u isto vrijeme izravno svjestan nečega — što je u nekom smislu izvan mene (Calkins, 1925, 208).

Ontološki rečeno, uključujuće sebstvo nije u potpunosti različito od kasnijeg hajdigerovoskog tu-bitka, no kod Calkins je važna svijest o vremenskoj blizini i razdaljini kontingentnog i apsolutnog bitka. U sadašnjem trenutku, ljudska svijest podjednako zahvaća u vlastito postojanje, kao i donekle u postojanje apsolutnoga. Kako onda Calkins definira apsolutni bitak ili apsolutno ja? Prvo, apsolutno ja je sve-uključujuće sebstvo koje nema ni trunke zbilje, kako god ona bila trivijalna. Drugo, ono je cjelina dijelova ne u smislu neovisnih entiteta, nego u smislu Gestalt okolnosti (Calkins, 1962, 212). Iako je Calkins nastojala pomiriti apsolutizam i personalizam, postojanje hegelijanskog bitka s postojanjem osobe, ipak se u svojem istraživanju kao i Hickok referira na fenomene budnosti, sna, svijesti i emotivnih stanja, zbog čega možemo konstatirati da je personalni apsolutizam tek filozofski pokušaj odgovora na pitanje kako samosvijest, moj ja funkcionira izvan empiričke psihologije.

\section{Profilirani personalizam Bostonske i Kalifornijske škole}

Iz okrilja akademskog buđenja filozofije kao zasebne discipline koja se izlaže na sveučilištima, pojavljuju se personalističke škole u Bostonu i Kaliforniji, čije temelje postavljaju Borden P. Bowne i George Howison. Metodološki, Bowne i Howison polaze od problematike ljudske osobnosti, iako su njihovi ciljevi drukčiji. Bowne, kao metodistički svećenik i teolog, zastupa teistički karakter personalizma u kritičkoj analizi idealizma, naturalizma i materijalizma. Na sličan način i njegovi učenici Flewelling, Brightman, Knudson i Bertocci u svojim se djelima osvrću na povijesnu pozadinu te polemike, koja je još bila prisutna kod Emersona i Alcotta. S druge strane, Howison svoj personalizam gradi na zasadama idealizma, na kojeg naslanja i svoju teoriju društva. 


\subsection{Teistički personalizam Bordena Parkera Bownea}

Borden P. Browne rođen je 28. siječnja 1847. u Leonardsvilleu, saveznoj državi New York. Nakon gimnazijskog i akademskog školovanja u Europi, počeo je predavati na Sveučilištu u Bostonu. U istom gradu iznenada je umro 1. travnja 1910. godine. Kako George Coe ističe u novinskoj objavi o njegovoj smrti, cjelokupan Bowneov filozofijski rad određuje prvo kritičko djelo o Herbertu Spenceru, u kojem brani drevnu vjeru u smislenost svijeta i njegovu inteligibilnost (Coe, 1910, 281). Kritika Spencerova materijalizma predstavlja početak Bowneova bavljenja personalističkim pitanjima, u kojima se nadahnjuje na spoznajama svojeg učitelja Lotzea.

Flewelling je kasnije u svojoj knjizi Personalizam i problemi filozofije podcrtao neke od sličnosti i razlika između Lotzea i Bownea, koje se prije svega tiču Bowneova načelnog teizma i problematike strukture svijeta. Obojica su se distancirala od pluralizma, odnosno atomizma kao i od apsolutnog idealizma (eng. absolutism) jer ni u jednom od tih koncepta stvarnosti sloboda i individualnost nisu zajamčene (Flewelling, 1915, 104). Iako se Lotze u svojoj filozofiji nije utoliko bavio pitanjem Božje osobnosti, ono je bitno za Bownea. Štoviše, problem ljudskog iskustva materije u stvarnosti koja nastaje, prolazi i propada ne može se riješiti na razini konstatacije danog fenomena. Za Bownea osobnost je takva kao »jedina moć koje smo svjesni i koja može združiti raspršene doživljaje vremena i prostora u cjelinu, i promotriti je s jednog jedinog vidika (Flewelling, 1915, 106). Bowne osobnost izjednačava s epistemološkom vrlinom jer bez nje ne bismo stekli puni uvid u zbilju koja je prije razlomljena na različite fragmente percepcije, zbog čega kritizira materijalističko shvaćanje spoznaje. Materijalistički aspekt naglašava trenutnost i nepostojanost percepcije te se sumnja u samu narav svijesti, koja po Bowneu mora biti osobna. Stoga ćemo se u ovom odjeljku prvo osvrnuti na teističku kritiku Spencerova materijalizma, a zatim na problematiku religije, spoznaje i generalne slike o personalizmu.

\subsubsection{Kritika Herberta Spencera}

Spencerova materijalistička filozofija počiva na evolutivnoj definiciji prirode i promjena koje se u njoj odvijaju. Možemo reći da je Spencer u svojoj filozofiji više afirmirao agnosticizam, a ne ateizam. Njegova filozofija toliko ne negira apsolutno božansko koliko teistički koncept Boga, što je Bowne htio izložiti u svojoj kritici. U Filozofiji Herberta Spencera Bowne izlaže kritiku Spencerova materijalizma analizirajući zakone spoznatljivoga i nespoznatljivoga, kako bi nakon toga prikazao teistički argument uz načela psihologije. Na prvim stranicama Bowne naglašava da teizam i evolucija ne moraju biti u sukobu jer se teizam bavi pitanjem postoji li nekakav Um koji je prvotni uzrok svemira i njegov vječni upravitelj (Bowne, 1874, 10). Možemo konstatirati da Bowne ne upire svoju kritiku prema znanstvenim podlogama Spencerova materijalističkog tumačenja evolucije koliko je ta kritika upućena prema filozofskoj argumentaciji istoga, koja lako klizi prema panteizmu i agnosticizmu. 
U prilog tomu navodi da su njegovi zakoni nespoznatljivoga protkani terminima poput: neuvjetovanoga, uvjetovanoga, apsolutnoga, beskonačnoga (Bowne, 1874, 28). Ti se termini s pravom koriste u metafizici, no to ne znači da bi metafizika bila manje objektivnija od prirodoslovnih znanosti. Spencer, koji vrednuje empiričku znanost koja počiva na informacijama danima u percepciji (pokus i opservacija) zaboravlja da su prirodni zakoni koji bi trebali graditi neku znanstvenu teoriju također apstraktni, jer tko primjerice može steći znanstveno znanje na temelju tog pristupa koji čini njezin neznatni dio? (Bowne, 1874, 31). Bowne brani teističke postavke od Spencerova materijalizma jer po toj kritici ni sam Spencer u dovoljnoj mjeri ne diferencira filozofiju, znanost i religiju, njihove vlastite metode i dosege.

\subsubsection{Osoba u središtu kršćanske apologetike}

Bowne je mnoga djela posvetio apologetici kršćanstva nasuprot tendencijama panteizma, ateizma i materijalizma. Djela kao što su Studies in Christianity (Boston, 1909.), The Essence of Religion (Boston, 1911.) i Theism (New York, 1902.) Bowne je napisao s ciljem filozofske argumentacije kršćanske vjere kao jedine istinite vjere, $\mathrm{u}$ čemu nema jasne razlike između fundamentalne teologije koja se bavi objavom i teizmom kao zasebnim filozofsko-teološkim sustavom koji nije ograničen na kršćanstvo. Kako je Bowne ugradio koncept osobnosti u apologetiku?

Ako teisti poput Bownea tvrde da je Bog u jednakoj mjeri transcendentan i imanentan prema svemiru, proizlazi da naši atributi ne mogu do kraja opisati narav Božje osobe. No, ako tvrdimo da je Bog, kako je mislio Schopenhauer, tek neka slijepa volja koja proizvoljno producira, onda Bogu pripisujemo besmislene atribute, jer tvrdi Bowne, volju ne možemo definirati bez svrhe i ciljeva koje volji zadaje samo osoba koja je racionalna (Bowne, 1902, 157). Tvrditi da volja može postojati bez osobe koja je posjeduje za Bownea je krajnje nelogično, u čemu možemo prepoznati središnji položaj osobnosti u njegovu teizmu. Bowne zato često koristi termin impersonalizam kako bi čitatelju naglasio da su filozofije materijalizma ili panteizma "impersonalne" filozofije, to su filozofije u kojima se gubi osobnost, što se ne može tvrditi za kršćansku filozofiju.

\subsubsection{Personalizam}

Zbirka eseja nazvana Personalizam objavljena je 1908., par godina prije Bowneove smrti. U njoj se Bowne prvo obraća filozofima i njihovim različitim poimanjima zdravog razuma (common sense), znanosti pa i o naravi same filozofije. Iako filozofija, strogo rečeno, mora posjedovati logičku i sistemsku uređenost, Bowne navodi kako o filozofiji možemo govoriti šire nego što bi zahtijevali okviri akademizma. Filozofija je filozofijsko mišljenje, jednostavno, pogled u stvarnost kojeg agnostici, materijalisti, panteisti i teisti drukčije tumače (Bowne, 1908, 4). Filozofirati može svatko, svaki pojedinac, što nam već donekle rasvjetljuje Bowneov personalistički osvrt na common sense. Kako ga on definira? Prvo, common sense pretpostavlja koegzistenciju različitih osoba koje čine neku duhov- 
nu zajednicu. Drugo, postoji zakon racionalnosti koji upravlja tom zajednicom. Treće, pretpostavlja aktualni ili mogući svijet u kojem postoji zajedničko iskustvo, kao i njegova racionalna artikulacija (Bowne, 1908, 21). Koncept zdravog razuma stoga u sebi povezuje tri presudna nadopunjujuća elementa: zajednicu osoba koje su među sobom različite po svojim spoznajama; zakon racionalnosti koji stabilizira njihove spoznaje do nekih zajedničkih zaključaka; aktualni ili mogući svijet u kojem postoji dogovor oko valjanosti univerzalnih spoznaja. Bowne ne sumnja u načela zdravog razuma jer je svaki čovjek u neku ruku filozof, nego se vraća problematici pojedinačnog iskustva i znanja u nakani jasnog razgraničenja impersonalističkih i personalističkih tumačenja svijeta u kojem se formiraju spoznaje.

Za razliku od svojih predšasnika koji su u personalizmu veći naglasak stavljali na komunitarni karakter znanja, pa i onog religioznog, Bownea fascinira isključivo iskustvo i dosezi spoznaje, jer u svojem djelu polemizira s gledištima po kojima pojedinačno iskustvo i ne može biti presudno za spoznaju, primjerice idealizam i materijalizam. Njegova je kritika upućena i krivomu tumačenju zdravog razuma, koji bi se trebao referirati samo na predodžbu fiksirane fizičke stvarnosti kojom upravljaju apstraktni zakoni jer, kako tvrdi, jedina je realnost Bog, inteligencija koja regulira promjenama u fizičkom svijetu, i bez koje bi postojanje pojedinačne svijesti bilo zapravo besmisleno (Bowne, 1908, 157). Inteligibilnost fizičke stvarnosti ne ograničava se na predodžbe kakve fingira znanstvena teorija jer se to protivi sposobnostima osobne svijesti, spoznaje i iskustva uvijek spekulativno otvorenima području izvan same empirije. Kako bi produbio personalističku kritiku common sense, Bowne se u četvrtom poglavlju osvrće na mehanicistički i voluntaristički aspekt kazualiteta, u kojem možemo iščitati da je mehanicizam impersonalistička, a voluntarizam personalistička koncepcija.

Nakon ovog uvida u Bowneovu kritiku materijalističkog vida stvarnosti i impersonalizam mehanicističkoga gledišta na kauzalitet, zadnja dva poglavlja Personalizma donose odgovore na pitanja: prvo, zbog čega impersonalizam nije uspio i, drugo, što je osobni svijet (the personal world)? Materijalizam, idealizam, kao i filozofski naturalizam, ne mogu dati definiciju ljudske osobe jer su okrenuti njegovim pojedinačnim i izoliranim aspektima, koji se ponajprije tiču epistemološkog problema. Spoznaja se prema tim filozofskim aspektima ograničava: ili se ističe materijalistička podloga koja preferira percepciju osjetila tako da se preispituje postojanje samosvijesti osobe s praktičnim posljedicama, ili se, kao u idealizmu, negira realitet, odnosno zasebnost objekta iskustva.

Kako su ti vidici stoga impersonalni, Bowne konstatira da je polazište impersonalizma korporalno, odnosno polazi od prvenstva fiziologije, što je suprotno personalizmu, jer je

bitno značenje osobe sebstvo [selfhood], samosvijest, samokontrola kao i moć spoznavanja. Te sastavnice nemaju korporalno značenje i ne mogu se ograničiti. Svako biće, konačno ili beskonačno, koje posjeduje znanje, samosvijest i samokontrolu, je osobno; i nema druge definicije (Bowne,1908,266). 
Poznavajući problematiku evolucije kao i Bergsonov vitalizam, Bowneu je još preostalo odgovoriti kako se osobnost manifestira kao živo biće, kao čovjek unutar zajednice s kojom dijeli svoje spoznaje i osjećaje. Bowne se nadovezuje na pozitivističko poimanje društva na čiju transformaciju utječu prirodni uvjeti, čije utjecaje isto društvo religiozno-simbolički interpretira, slijedom toga i religija nastaje kao proizvod društvene zajednice koja ima svoju povijest, kao i teritorijalni položaj, svoj prostor i vrijeme. Personalizam svakako gleda na osobu izvan tih determinacija, i time se ponovno otvara teističkomu pitanju o Božjoj osobnosti. Panteizam naravno povlači paralele između Apsolutnoga i ljudskog duha, njegovih i naših misli, što je psihološki proturječno i ne može zamijeniti religiju (Bowne, 1908 282). Teističke religije polaze od temeljnog postulata da su Bog i čovjek nemjerljivo ontološki različiti, što se reflektira na društvenu zbilju, pri čemu Bowne apologetski pristupa problematici summum bonum u povijesti religija.

Vjera u poganska božanstva, kao i ona u Boga filozofa ili Boga skolastičke teologije, po njegovu je sudu, napuštena (Bowne, 1908 297). Takvi koncepti vjerovanja u Boga kao vjerovanje u najveće Dobro ne mogu odgovarati trenutačnim okolnostima ljudske potrage za istinom. Bowne opet ne vidi da ijedna religija može odgovarati personalističkim načelima do one u kojoj se vjeruje istodobno u Boga i čovjeka (Bowne, 1908 299). Teistički personalizam Bordena Bownea izgrađen je na kritičkoj polemici sa suprotnim filozofskim pravcima, u kojoj je njegov personalizam zasjenio prijašnje pokušaje argumentacije i sustavnog izlaganja. No, njegov personalizam također je određeni oblik apologetskog nastojanja da se istine kršćanske vjere, u Bowneovu slučaju, metodizma suoče s ondašnjim tendencijama u politici, društvu i znanosti.

\subsection{George H. Howison (1834.-1916.)}

Howison je prvotno predavao na Tehnološkom institutu u Massachusettsu, a zatim se, tražeći sebi prikladnu filozofiju, nakon lutanja po Europi i Središnjoj Americi, naselio u Kaliforniju i tamo počeo predavati na Sveučilištu Berkeley (Schneider, 464). Njegov oblik personalističkog nauka naziva se i personalistički ili pluralistički idealizam, čija je načela Howison skovao i prikazao u svojem poznatom djelu The City of God. S pretpostavkom da se nadahnuo djelom sv. Augustina, i Howison u tom djelu povezuje problematiku pojedinca s ustrojstvom demokratske vlasti i pitanjem o naravi Božje osobnosti. Kako je prije spomenuto, i kod Howisona se premeće teistička apologetska problematika osobe Boga, što je utjecalo i na odjek Howisonova personalizma kod studenata i ostalih slušatelja.

Naime,

Howison je došao do jedne radikalne demokratske koncepcije personalističkog idealizma koji je obuhvaćao čak i Boga, koji u toj koncepciji više ne predstavlja svemoćnog monarha, upravitelja ili stvoritelja svemira, nego zadnjeg demokrata u vječnim relacijama s ostalim vječnim osobama. Stoga nije čudo što Howison nije stekao učenike među religioznima ni među onima koji su se smatrali nereligioznim, a kojima 
je njegov idealizam bio i suviše religiozan; njegovomu idealizmu jedino bi bio sličan idealistički ateizam McTaggarta ili apeironizam Thomasa Davidsona (McLachlan, 2006, 224).

Unatoč tomu što njegov personalistički idealizam ne možemo nazvati religioznim ni ateističkim, ipak je u njemu i dalje prisutna stanovita kontroverza po pitanju Božjeg postojanja kao osobe. Američki filozofi skloni personalistilčkoj misli svakako nisu dvojili oko načelnog postojanja Boga, koliko su htjeli teistički koncept o njemu pomiriti sa spekulativnom filozofijom. Za kršćansku teologiju kalvinističke baštine to pitanje uopće nije bilo sporno, no u filozofskim krugovima, osobito pod utjecajem deizma i naturalizma, ono je bilo i dalje otvoreno.

U jednoj od svojih rasprava s Royceom, Howison brani svoj koncept o pojedincu i društvenom ustroju kao refleksiji moralnog reda. Postoje tri uvjeta koji omogućuju individualnost osobe: prvo, u svemiru postoje individualna središta iz kojih nastaje mnoštvo vječnih bića; drugi uvjet leži u međusobnoj odgovornosti individualnih središta koja prepoznaju svoju i tuđu posebnost; treće, središta iz kojih nastaje ljudska individualnost čvrsto su povezana s božanskim izvorom, iz čega možemo zaključiti da je zbilja ili teistička ili ateistička, jer ako su svi ljudi vječni, onda su bogovi tako da koncept jednog Boga postaje suvišan (Skrupskelis, 1994, 795-796). Takvo viđenje poretka društvene i prirodne zbilje teško je pomiriti s temeljima kršćanskog teizma. Ipak, Howison svakako ne izjednačava politeizam s teizmom: pojedinac nije inicijalno jednak s Bogom, nego to može postati.

Howison smješta Boga na čelo svojeg nebeskog grada po načelu finalne kauzalnosti, Bog je ideal ideala, božansko usavršenje, približavanje osobe takvomu idealu putem moralnog života oblikuje i cijelu društvenu zajednicu, čineći ju gradom Božjim (Skrupskelis, 1994, 797). Čini se kako je Howison blizak moralnomu perfekcionizmu, slično Emersonu i Thoreau. No, za razliku od Thoreaua, introspekcija o transcendiranju prirode nije isključivi cilj u životu pojedinca, kako ga podrazumijeva Howison. Royce je kritizirao Howisonov idealizam sumnjajući kako sadržava primjese individualizma, koji je prezirao. Ipak, Howison nije nudio svoju filozofiju kao alternativu kršćanskomu poimanju osobe. On je ugradio vrjednote koje je zapadnjačka misao već posjedovala od samih početaka, iako ih je artikulirao na način u kojem bi, kao i njegovi prethodnici, pomirio idealizam s personalizmom (Skrupskelis, 1994, 799). Iako Howison u svojem personalizmu nije odbacio teizam, njegov je personalizam zbog mnogih elemenata bliži panteizmu. U svojoj je filozofiji teško i na nedovoljno jasan način približio apsolutni idealizam teističkomu personalizmu, u čemu je ipak prednjačila bostonska škola.

\subsection{Personalizam poslije Bownea i Howisona}

Bowne i Howison svojim su djelima dali smjer daljnjemu razvijanju personalističke misli u 20. stoljeću. Njihov rad nastavili su Knudson, Brightman i Bertocci u Bostonu te Flewelling u Kaliforniji, koji je zaslužan za pokretanje časopisa The Personalist. Ta četvorica personalista ujedno su i metodistički teolozi, neki od njih i zaređeni službenici, te se može zaključiti da su personalističke teme nastavili produbljivati u teističkom, apologetskom pravcu, iako je primjetan i po- 
vijesno-filozofski pristup u nastojanju da se dotadašnja povijest personalističke misli razvrsta, sumira i sustavno prikaže. Možemo konstatirati da je poslije Bordena Bownea jedino Albert Knudson sustavno izložio personalizam kao zaseban filozofski pravac.

\subsubsection{Doprinos Alberta Knudsona}

Albert Cornelius Knudson (1873.-1953.), potomak norveških emigranata, proveo je predavačku karijeru na Sveučilištu u Bostonu, kao i na Visokom teološkom učilištu u okrilju Metodističke Crkve. Godine 1927. objavljen je opsežni priručnik iz filozofije religije pod naslovom The Philosophy of Personalism, što nam na prvi pogled rasvjetljuje autorovu nakanu povijesne i kritičke analize filozofskih problema s gledišta personalizma. Slično Bowneu, Knudson također gradi personalistički pristup problemima u epistemologiji, ontologiji, kao i filozofiji religije. Ono što bi trebalo izdvojiti njegov je pokušaj definiranja personalizma, kojemu posvećuje prvo poglavlje svojeg priručnika.

U poglavlju Personality and God Knudson navodi različite primjere u povijesti filozofije u kojima se personalizam definira na temelju filozofijskog razumijevanja naravi Božje osobe: imamo ateistički personalizam McTaggarta, apsolutni personalizam ili personalistički apsolutizam kod američkih filozofa Roycea, Hockinga i Calkins, relativistički personalizam Renouviera, Howisonov personalni idealizam i, na kraju, tipični teistički personalizam, čije temelje Knudson nalazi kod Leibnitza, Lotzea i Bownea. Iako je teizam bliži personalizmu od ostalih filozofskih sustava, Knudson ipak naglašava da teizam počiva na pokušajima racionalnog argumentiranja Božjeg postojanja, a osobna je volja u personalizmu jedini most između uma i stvarnosti, a ne isključivo racionalnost (Knudson, 1927, 67). Osim što je ukratko izložio povijest personalizma, Knudson je ponudio i razvoj koncepta osobnosti.

U poglavlju The Concept of Personality Knudson navodi antičke i skolastičke izvore tog koncepta, čije tragove pronalazi u antičkoj filozofiji, a sam koncept dobiva svoju jasnoću tek kod Boecija i njegovoj definiciji: persona est naturae rationabilis individua substantia (Knudson, 1927, 81). Dalje se koncept osobnosti razvijao u raspravama o mogućnostima i slobodi ljudske osobe. Stoga Knudson zaključuje da koncept osobnosti nakon Kanta i Lotzea postaje središtem novog metafizičkog sustava tek kod njegova učitelja Bownea, novog sustava kojeg naziva sustavnim metodološkim personalizmom (Knudson, 1927, 85). Uvidjevši cjelokupan Knudsonov napor da personalistička mišljenja svojih predšasnika i suvremenika obuhvati u preglednu cjelinu davši mu karakter neovisne filozofske discipline, možemo konstatirati da je kod Knudsona personalizam u američkoj filozofiji sjedinio u sebi elemente spekulativne filozofije, epistemologije, teizma i apologetike, koji su također prisutni i u njegovim djelima o biblijskoj teologiji Starog zavjeta, posebice o prorocima i mudronosnim knjigama. 


\subsubsection{Brightman, Flewelling i Bertocci}

Osim Knudsona, personalizmom su se bavili njegovi suvremenici, Brightman, Flewelling i Bertocci. Edgar Scheffild Brightman (1884.-1953.), za razliku od Knudsona, približava se liberalnoj teologiji, točnije, njemačkomu teologu Ritschlu, kojega obilježava moderni fideizam. Ritschl, kako Brightman smatra, promatra teologiju kao strogu znanost čiji se predmet istraživanja svodi na sadržaje vjere zajednice koja je u odnosu prema Bogu uvjetovana oproštenjem grijeha (Brightman, 1917, 214). Drugim riječima, Ritschl polazi od sadržaja vjere koja ničim nije zaslužena, nego Božjim milosrđem, u čemu je dakle uloga razumskog shvaćanja Boga sekundarna, što ne znači da je irelevantna. Takav je stav vidljiv kad je riječ o odnosu Objave i razuma. Brightman ne ulazi, poput prethodnika, u raspravu u kojoj mjeri bi autonomna uloga razuma bila impersonalistička ako se pozitivizam ili common sense temelje na takvoj funkciji, pri čemu bi dakle i sadržaj vjere bio impersonalan (deizam, idealizam). Ako razum u odnosu na vjeru već pretpostavlja da Bog postoji, onda mora prihvatiti da se i sadržaj objavljenog ne protivi razumu, što nas dakle vodi ka zaključku da ni samog sučeljavanja razuma i vjere ne može biti, što bi postavilo u pitanje njihov identitet (Soper, 1955, 207). Iako je Brightman u svojim djelima dotaknuo problematiku individualizma u smislu impersonalizacije osobe kao društvenog bića, tek kod Flewellinga nailazimo na opsežnije analize.

Ralph Tyler Flewelling (1871.-1960.) poznatiji nam je u američkom personalizmu zbog revije The Personalist, koju je pokrenuo 1920. u suradnji sa sveučilištima u Bostonu i Los Angelesu. Flewelling svoj sustav naziva i personalističkim realizmom, koji spominje u svojim djelima o Bergsonu i Bowneu. Flewelling poput Knudsona također objavljuje priručnik iz filozofije s osobitim osvrtom na personalizam Bordena Bownea. U knjizi pod naslovom Personalism and The Problems of Philosophy iz 1915. godine Flewelling analizira povijest personalizma s osobitim naglaskom na doprinose Bownea i Euckena. U četvrtom dijelu knjige uspoređuje personalizam Bownea, Euckena i Bergsona. U kritici Bergsonova učenja o intuiciji i intelektu, Flewelling se vraća odnosu vjera-razum: smatra da je Bergsonova doktrina neprimjenjiva, jer kako bismo onda trebali tumačiti religiozno ponašanje u primitivnim zajednicama, ovisi li ono o nagonima pojedinaca ili uključenosti razuma u razvoj te i te religioznosti? (Flewelling, 1915, 166). Flewelling u Bergsonovu učenju prepoznaje udaljavanje razuma i vjere, a u izlaganju o Bowneu ističe da jedino u personalizmu nailazimo na komplementarnost svih aspekata ljudske osobe.

Kako je spomenuto, Flewelling je pokrenuo časopis The Personalist, za koji su pisali autori s različitih humanističkih područja. Tako je prvi broj posvećen povijesno-filozofskim temama o personalističkoj misli, Bowneu, edukaciji, kao i teološkim pitanjima o spoznaji Boga (Flewelling, 1920). Teme iz Personalista polako izlaze iz akademskih kružoka te se približavaju tijekovima u Europi, u kojoj personalizam ne predstavlja samo filozofski pravac, koliko i zaseban model političkog djelovanja i života. Kao zadnjeg predstavnika personalizma 20. stoljeća na američkom tlu spomenut ćemo i Petera Anthonyja Bertoccija (1910.-1989.), 
koji je također bio Bowneov učenik i Brightmanov suradnik. U svojem djelu o empiričkom dokazu za Božje postojanje u kasnoj engleskoj misli Bertocci izlaže kritiku personalizma kod Jamesa Worda i Fredericka Tennanta (Bertocci, 1938).

\section{Ostale grane personalizma u Sjedinjenim Državama}

Kako smo do sada izložili, personalizam se u Sjedinjenim Država razvijao na poznatim sveučilištima i u okviru akademske djelatnosti predavanja i objavljivanja. Doprinos personalizmu u Sjedinjenim Državama dali su i europski mislioci koji su došli u Ameriku što zbog ratnih, što zbog akademskih razloga, kao Maritain, Gilson i Voegelin. Jacques Maritain i Etienne Gilson utjecali su na razvoj neotomističkog personalizma u Sjedinjenim Državama (sveučilište Notre Dame u Indiani i École Libre des Hautes Étude u New Yorku), a Eric Voegelin bavio se s pitanjem osobnosti u novoj znanosti o politici. Osim europskih intelektualaca koji su boravili u Sjedinjenim Državama, potrebno je spomenuti personaliste koji su se bavili identitetom Afroamerikanaca i njihovom integriranošću u američko društvo, kao i one koji su se nadahnjivali pučkom mudrošću američkih starosjedilaca. Iako su se u svoje vrijeme Emerson, Alcott i Whitman angažirali oko abolicije Afroamerikanaca, integracija u američko društvo postala je personalističkim pitanjem. Ne treba zanemariti ulogu Williama Edwarda Du Boisa (1868.-1963.) i njegov sociološki pristup problematici crnačke populacije. U kontekstu bostonskog personalističkog kruga, treba spomenuti Johna Wesleya E. Bowena (1855.-1933.). Bowen se rodio u New Orleansu, no većinu svojeg propovjedničkog i predavačkog vijeka proveo je na sveučilištima Boston i New York. Iza sebe je ostavio velik broj monografija, radova iz političke teorije, novinskih članaka, filozofije, teologije i edukacije (Caldvell, 1917). Bowenov je rad utjecao na Martina Luthera Kinga (1929.-1968.), koji je personalističke ideje pretočio u politički aktivizam.

Vine Deloria (1933.-2005.) predstavnik je indijanskog personalizma, koji je, slično afroameričkomu, nastajao usporedo s političkim aktivizmom predstavnika indijanskih plemena u javnosti. Deoloria se bavio antropologijom i arheologijom te je dobro poznavao povijest, etnologiju i religiju svojeg naroda. Iako nije riječ o personalizmu u strogom smislu, njegove interpretacije starosjedilačke kulture, kolektivnog sjećanja i religioznog iskustva prirodnog svijeta mogu se nazvati personalističkim jer nam daju uvid u poimanje osobe koje su američki starosjedioci gajili prije i poslije bjelačke kolonizacije kontinenta.

\section{Zaključak}

Personalističke ideje o dostojanstvu osobe bile su prisutne još u svjetonazoru prvih naseljenika pristiglih u Sjevernu Ameriku nakon političkih i vjerskih progona na starom kontinentu. Pitanje osobe kod puritanaca i deista ujedno je i pitanje o sekularnoj naravi političke individualnosti, što ostaje aktualno sve do razdoblja 
Emersona i njegovih učenika. Umjesto filozofski preciznog pristupa personalističkim pitanjima, transcendentalisti kao Thrudeau i Whitman romantičarski zamišljaju društvo individua u buntu protiv prosvjetiteljskog, poslijeratnog normiranja demokratskog društva. Poslijeratni personalizam obilježen je Alcottovom kritikom individualizma, koji Alcott povezuje s panteizmom. Ono što je panteizam u religioznoj filozofiji, to je individualizam u političkoj praksi transcendentalista, i Alcott je uveo pojam impersonalizma, s kojim su američki personalisti obilježavali kasnije sve filozofske pravce koji na ovaj ili onaj način negiraju osobnost. Personalistička misao poslije Alcotta razvijala se pod utjecajem teizma, idealizma i psihologije. Hickok i Calkins slijede Hegelov apsolutni idealizam, iako ga nastoje pomiriti s personalističkim idejama o samosvijesti i identitetu.

Profilirani personalizam na sveučilištima Boston i Južna Kalifornija nije samo teistički, nego i apologetski ustrojen. U teističkom personalizmu kritika nije toliko upućena idealistima koliko materijalizmu Herberta Spencera i filozofskomu naturalizmu. Borden Parker Bowne kritički je orijentiran kako prema idealističkoj prošlosti tako i suvremenim gibanjima u kojima se gube granice filozofije i znanosti što prepoznaje kod Spencera. Pod utjecajem metodističke teologije, Bowne gradi svoj personalizam i kao stanovitu apologetiku kršćanske vjere nasuprot tendencijama u kojima se relativizira kršćanska Objava, primjerice u pozitivizmu i historicizmu. Za razliku od Bownea, Howison se u svojem personalnom idealizmu vraća na problematiku individualnosti, nastojeći obrazložiti koncept o Bogu kao svrsi moralnog usavršavanja svake osobe, pa tako i društva. U trećem razdoblju, od prve polovice 20. stoljeća na ovamo, Bowneovi učenici, filozofi i teolozi, poput Brightmana, Knudsona i Flewellinga, nastoje prikazati personalizam u svjetlu povijesti američke filozofije, ali mu i dati više prostora u znanstvenim krugovima, čemu je zaslužan Flewelling i časopis The Personalist. Širenje interesa za personalističku misao među humanističkim krugovima rezultiralo je integracijom temeljnih personalističkih koncepata kao što je ljudsko dostojanstvo u javni politički diskurs, što je prisutno kod predstavnika afroameričkog i indijanskog personalizma.

Ukratko, personalizam u Sjedinjenim Američkim Državama možemo opisati u nekoliko točaka. Prvo, personalizam na tlu SAD-a profilirao se u kritici individualizma i impersonalističkih postavki u idealizmu. Drugo, razvoj sjevernoameričkog personalizma obilježava pitanje o inteligibilnosti stvarnosti. Različiti pravci u personalizmu nastaju u nesuglasju oko naravi Božje osobe kao temelja stvarnosti. Teistički personalisti brane tezu da je osobni Bog taj koji je pokrenuo svijet i održava ga, a primjerice apsolutni personalisti skloniji su panteizmu. Treće, razvoj sjevernoameričkog personalizma obilježava polemika u kojoj teistički personalisti apologetski razlažu istine kršćanstva nasuprot tendencijama koje se s njihove strane nazivaju impersonalističkima, a bliske su ateizmu i relativizmu. Između personalizma u SAD-u i onog u Europi svakako ima puno sličnosti, što bi trebalo ostaviti nekoj drugoj analizi. Kako god se činilo da je sjevernoamerički doprinos personalizmu minoran, on je podjednako važan kao što je njegov doprinos filozofiji jezika ili analitičkoj filozofiji, po čemu uvriježeno prepoznajemo doprinose američkih filozofa. 


\section{Literatura:}

Bertocci, Peter Anthony (1938). The Empirical Argument For God In Late British Thought. Cambridge: Harvard University.

Bowne, Borden Parker (1874). Philosophy of Herbert Spencer: Being an Examination of The Frist Principles of his System. New York: Nelson and Phillips.

Bowne, Borden Parker (1902). Theism. New York: American Book Company.

Bowne, Borden Parker (1908). Personalism. Houghton: Mifllin.

Brightman, Edgar Scheffild (1917). Ritschl's Criterion of Religious Truth. The American Journal of Theology, 4(1), 212-224.

Caldvell, Arthur Bunyan (1917). History of American Negro and His Instituions. Atlanta: A. B. Caldwell Publishing.

Calkins, Mary (1962). The Philosophic "Credo" of an Absolutic Personalist. U: George P. Adams i Montague W. M. Pepperell (ur.), Contemporary American Philosophy (str. 197-219). New York: Russell and Russell.

Calkins, Mary Whiton (1925). The Persistent Problems of Philosophy: An Introduction to Metaphysics through The Study of Modern Systems. New York: The MacMillan Company.

Coe, George A. (1910). Borden Parker Bowne. The Journal of Philosophy, Psychology, and Scientific Methods, 11(7), 281-282.

Devčić, Ivan (2003). Bog i filozofija. Zagreb: Kršćanska sadašnjost.

Flewelling, Ralph Tayler (1920). Contents for April, July, October. The Personalist, 1(1), $1-65$.

Flewelling, Ralph Tyler (1915). Personalism and The Problems of Philosophy: An Appreciation of The Work of Borden Parker Bowne. New York: The Metodist Book Concern.

Furtak, Rick Anthony (2012) Thoreau's Importance for Philosophy. New York: Fordham University Press.

Hickok, Laurens Perseus (1858). Rational Cosmology: The Eternal Principles and The Necessary Laws of The Universe. New York: D. Appleton and Co.

Hickok, Laurens Perseus (1875). The Logic of Reason: Universal and Eternal. New York: Shepard and Dilingham.

Knudson, Albert Cornelius (1927). The Philosophy of Personalism: A Study in Metaphysics of Religion. New York: The Abingdon Press.

Mautner, Thomas (ur.) (1996). The Penguin Dictionary of Philosophy. London: Penguin Books.

McLachlan, James (2006). George Holmes Howison: "The City of God" and Personal Idealism. Journal of Speculative Philosophy, 20(3), 224-242.

Miller, Perry (1953). The New England Mind: From Colony to Province. Boston: Harvard University.

Royce, Josiah (1952). Religious Philosophy of Josiah Royce. New York: Syracuse University.

Schepard, Odell (1937). The Life of Bronson Alcott. Boston: Little Brown and Company.

Schmidt, Bernard (1994). Alcott's Developing Personalism and the Argument with Emerson. American Transcendental Quarterly, 8(4), 311-328.

Schneider, Herbert W. (1946). A History of American Philosophy. New York: Columbia University.

Skrupskelis, Ignas K. (1994). The Royce-Howison Debate on the Concept of God. Transactions of the Charles S. Pierce Society, 3(4), 791-802. 
Soper, David Wesley (1955). Men Who Shape Belief Major Voices In American Theology: Volume II. Philadelphia: The Westminster Press.

Symonds, John Addington (1893). Walt Whitman: A Study. London: George Rutledge and Sons.

Taylor, Charles (1989). Sources of The Self: The Making of The Modern Identity. New York: Cambridge University.

\section{Personalism in the United States of America}

\section{Bruno Matos*}

\section{Summary}

The problem of the person - its structure with respect to sociological, religious and epistemic components - is present in North American philosophy since its early beginnings, from the time of Puritan idealism to the Boston and California schools. Since the middle of the eighteenth century, the issue of the personality or individuality is present in debates between the American Enlightenment and transcendentalists in which attempts are made to respond to questions on the kind of equal relationship which must be established among legally chosen authorities, institutions and the individual. The person was discussed in critiques on individualism which included elements of philosophical and theological discourse about the personality of God. Although idealism dominated in universities, and personalism was still of minor importance, it slowly became an equal interlocutor in academic discourse. American personalists did not impose their theories in the form of political programs or religious doctrines. Still, we discern therein separate philosophical reflections which, like personalism in Europe, strive to respond to the question of the person from the theological, sociological and scientific perspectives.

Key words: personalism, integrity, impersonalism, theism, society

* Bruno Matos, Ph.D., Catholic Faculty of Theology, University of Zagreb. Address: Vlaška ul. 38, 10000, Zagreb, Croatia.E-mail: bruno.vtz3@gmail.com 